\title{
Efforts and Concerns for Indigenous Language Education in Taiwan
}

\author{
Gao, I-An
}

Springer

2019

Gao , I-A , Lin , C-F \& Lin , P-I 2019 , Efforts and Concerns for Indigenous Language

Education in Taiwan . in E A McKinley \& L T Smith (eds), Handbook of Indigenous

Education . Springer , Singapore , pp. 443-465 . https://doi.org/10.1007/978-981-10-3899-0_11

http://hdl.handle.net/10138/329758

https://doi.org/10.1007/978-981-10-3899-0_11

unspecified

acceptedVersion

Downloaded from Helda, University of Helsinki institutional repository.

This is an electronic reprint of the original article.

This reprint may differ from the original in pagination and typographic detail.

Please cite the original version. 


\title{
Efforts and Concerns for Indigenous Language Education in Taiwan \\ Chen-Feng Joy Lin, I-An Grace Gao, and Pi-I Debby Lin
}

\author{
Handbook of Indigenous Education, Springer 2019 \\ https://link.springer.com/referenceworkentry/10.1007\% \\ 2F978-981-10-3899-0_11
}

Taiwan has over 16 tribes of Indigenous peoples, consisting of 42 local dialects from 3 major Austronesia language systems. Indigenous peoples in Taiwan have for centuries been assimilated into the surrounding Chinese Han culture. Following the international Indigenous people's rights movements in the 1980s, Indigenous peoples in Taiwan started a cultural and social movement, which resulted in the legislation of the Indigenous Peoples' Basic Law. The Basic Law leveraged room for negotiations to enact concrete efforts for Indigenous cultural revitalization. Language education is one of the most urgent priorities of this revitalization. The central government initiated a nationwide effort to preserve Indigenous languages. Two terms of the Six-Year Indigenous Language Revitalization Project have already been implemented by the government, which has laid the foundation for expanding Indigenous language education, including training Indigenous language teachers and developing an Indigenous Language Proficiency Certification. Many local governments are also involved in providing language learning opportunities for Indigenous children and youth, such as establishing Indigenous immersion kindergartens and incorporating Indigenous language curricula in elementary schools. Resources for online learning have also been designed, providing opportunities for learning Indigenous languages using computer and

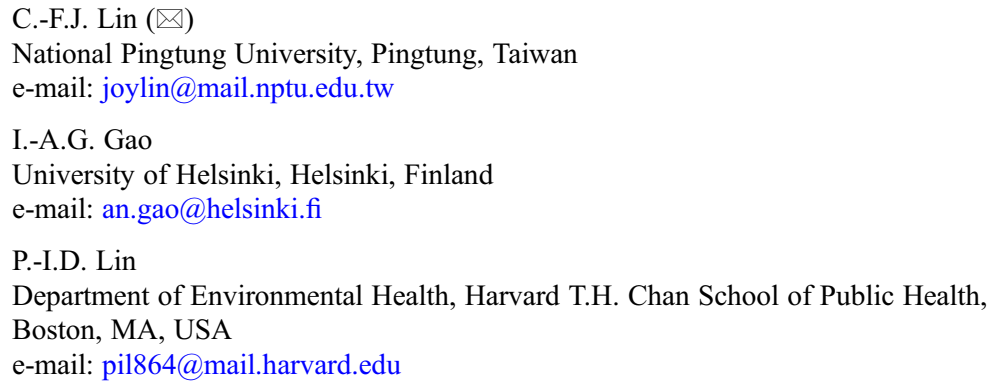


mobile technology. These top-down projects give rise to an increase of grassroots actions and awareness to preserve Indigenous languages has been intensified. This chapter provides an overview on works relevant to Indigenous language education in Taiwan and the challenges this project faces. Recommendations are given at the end to provide direction for future efforts on Indigenous language revitalization in Taiwan.

Indigenous education - Indigenous language - Taiwan • Indigenous language revitalization plan $\bullet$ Austronesian languages

\section{Contents}

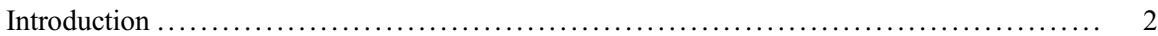

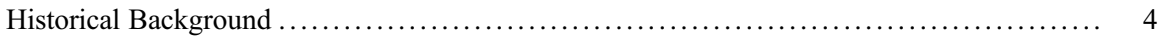

Legislative and Policy Support for Indigenous Language Education $\ldots \ldots \ldots \ldots \ldots \ldots \ldots \ldots \ldots$. 6

Current Condition of Indigenous Languages in Taiwan $\ldots \ldots \ldots \ldots \ldots \ldots \ldots \ldots \ldots \ldots \ldots \ldots . . \ldots$

Students' Attitudes Toward Learning Indigenous Languages $\ldots \ldots \ldots \ldots \ldots \ldots \ldots \ldots \ldots \ldots \ldots \quad 10$

Indigenous Language Education Policy and Projects in Taiwan $\ldots \ldots \ldots \ldots \ldots \ldots \ldots \ldots \ldots \ldots . \ldots \ldots$

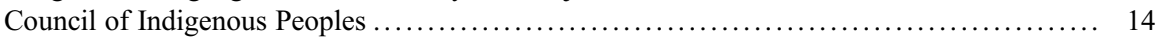

Six-Year Indigenous Cultural Revitalization and Development Project .............. 14

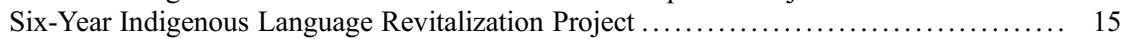

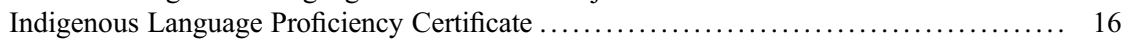

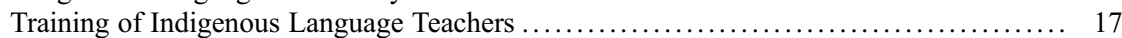

Online Learning Materials ................................................... 17

Indigenous Language Research and Development Center $\ldots \ldots \ldots \ldots \ldots \ldots \ldots \ldots \ldots \ldots \ldots \ldots$

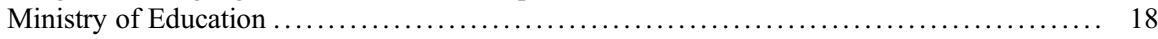

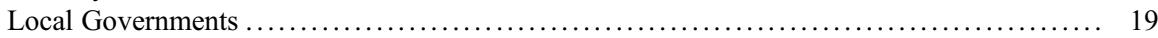

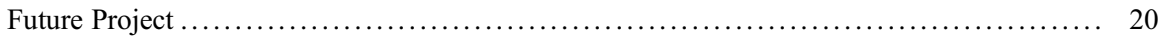

Challenges on Indigenous Language Education $\ldots \ldots \ldots \ldots \ldots \ldots \ldots \ldots \ldots \ldots \ldots \ldots \ldots \ldots \ldots, 21$

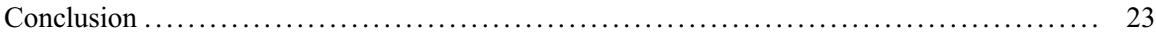

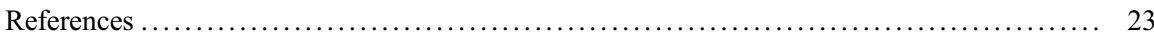

\section{Introduction}

Indigenous peoples make up about $2 \%$ of the total population of Taiwan, totaling 549,127 people as of May, 2016 (RIS 2016). The Council of Indigenous Peoples currently recognizes 16 Indigenous tribes. They are the Amis, Atayal, Paiwan, Bunun, Tsou, Rukai, Puyuma, Saisiyat, Yami, Thao, Kavalan, Truku, Sakizaya, Sediq, Hla'alua, and Kanakanava (Fig. 1).

Indigenous peoples in Taiwan speak languages belonging to the Austronesian family that encompasses 386 million people spreading from Easter Island in the east to Madagascar in the west, and from New Zealand in the south to Taiwan in the north (Bellwood 1991). Taiwan is believed to be the Austronesian homeland from a linguistic perspective (Blust 1984). About 24 Indigenous languages were found to be spoken in Taiwan up to the twentieth century, including Ketagalan, Taokas, Papora, Babuza, Favorlang, Hoanya, Siraya, Makattao, Taivoan, Kavalan, Pazeh, 


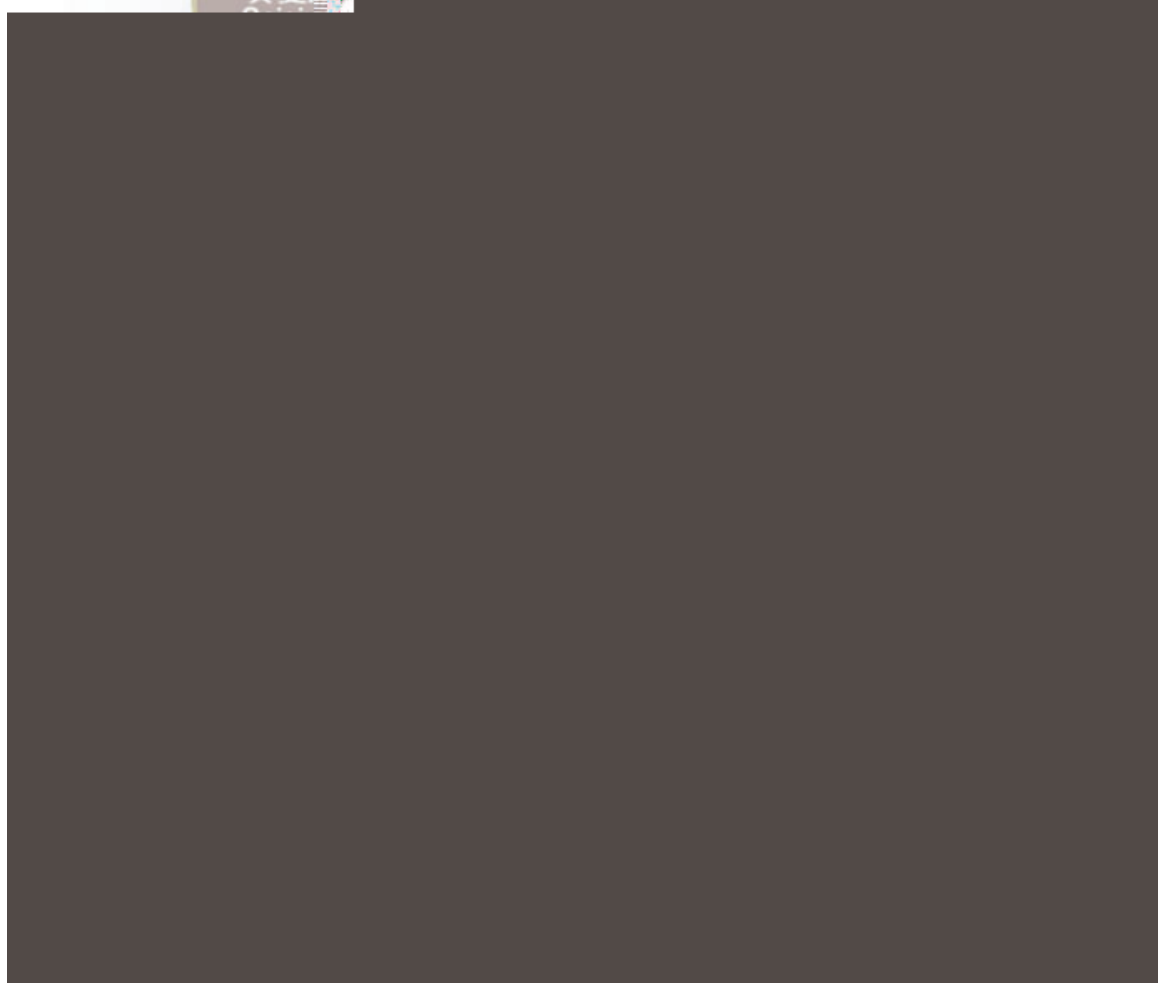

Fig. 1 Distribution of Indigenous tribes in Taiwan (Figure adapted from Taiwan Indigenous People's Knowledge Economic Development Association (2016))

Thao, Atayal, Saisiyat, Bunun, Tsou, Saaroa, Kanakanavu, Rukai, Paiwan, Puyuma, Amis, Seediq, and Yami. However, nine of the 24 languages (Keta[n]galan, Taokas, Papora, Babuza, Favorlang, Hoanya, Siraya, Makattao, and Taivoan) are already extinct (Zeitoun et al. 2003). Among the 16 officially recognized tribes, 42 local dialects have been recorded. The linguistic history of Taiwan is complex, demonstrating the diversity of the region.

A language is not only a tool for cultural exchange and communication but is also an important medium for passing on history, wisdom and cultural practices. Language provides evidence of an established society. However, with societal change, migration, and lack of support in the everyday environment, some languages face threats of extinction. What often eventuates is the emergence of a numerical or 











After the completion of the first Six-Year project, a second Six-Year Indigenous Cultural Revitalization and Development Project (2008-2013) was proposed, with a total budget of approximately USD 3.3 million (The second 6-Year Indigenous cultural revitalization and development project 2008; The Second 6-Year Indigenous Language Revitalization Project 2014). Its aims were (1) training of Indigenous professionals in history, culture, and art (including Indigenous Youth Cultural Enrichment Program); (2) research on Indigenous history, culture, and art; (3) enrichment of Indigenous museums; (4) creating environments to develop Indigenous music and dance; (5) subsidies for Indigenous communities to host traditional rituals and ceremonies; (6) promotion of all forms of artistic events; and (7) setting up offices for Indigenous cultural revitalization.

Compared to the first Six-Year project, the second placed more emphasis on art and culture. Due to the large scope of Indigenous language revitalization, a separate program was proposed that focused specifically on language revitalization efforts.

\section{Six-Year Indigenous Language Revitalization Project}

Indigenous languages education was included in the first Cultural Revitalization and Development Project, but the results were inconclusive. Due to the large scope and efforts required for language revitalization, a new project specifically focused on Indigenous languages was initiated in 2008. The funding for this project came from the central government, with a total budget of approximately USD $\$ 23.6$ million. This is the most important project for Indigenous language education, as it is the biggest nationwide project to target Indigenous languages specifically. The project had ten primary goals: (1) strengthen Indigenous language legislation; (2) establish Indigenous language organizations; (3) develop dictionaries for Indigenous languages and Indigenous language curricula; (4) promote research on Indigenous languages and development; (5) cultivate Indigenous language revitalization staff; (6) promote family-, tribal-, and community-based learning of Indigenous languages; (7) utilize multimedia and digital technology for teaching Indigenous languages; (8) implement Indigenous Language Proficiency Certification; (9) collect traditional and modern Indigenous songs; and (10) train specialists to translate policy, law, and regulations into Indigenous languages. The ultimate goals of the project are to preserve Indigenous languages as living languages in hope that, 1 day, Indigenous languages can be incorporated as official languages of Taiwan.

After the implementation of the First Six-Year Indigenous Language Revitalization Project, several problems were identified, including the slow progress on language revitalization, the rise of diverse learning media, the hardship of promoting the Indigenous Writing System, the urgency of saving endangered languages, and the lack of Indigenous language specialists. In addition, the numerous dialects and their complexity made the language revitalization process even more challenging. In the Second Six-Year Indigenous Language Revitalization Project (2014-2019), six main goals were set out to address these challenges. The first goal is to strengthen the connection between Indigenous languages and families where languages are used. 
There it is vital to create a family learning environment. It is evident that reviving the connection is essential to ensure successful languages revitalization. To build on the experience of the first 6-year program, the second 6-year program will continue to work on making "speaking and learning Indigenous languages" the trend in the Indigenous society.

The second goal is to build a comprehensive learning system from the cradle to the grave. The emphasis is placed in developing a systematic learning process, starting with Indigenous language immersion in preschool to adult education. In addition, digital technology is employed to make learning Indigenous languages more efficiently. Apart from the abovementioned enabling environmental factors to revitalize Indigenous languages, the role of specialists should not be overlooked. Therefore, the third goal of the project is to train Indigenous language revitalization specialist. To ensure specialists being sustainable, a comprehensive training system for Indigenous language revitalization specialists is warranted, including four levels of training (basic, beginner, advanced, and professional). Collaboration is urgently needed with higher education institutions that provide master and $\mathrm{PhD}$ programs in Indigenous language studies. Funding for short-term study abroad and for attending international conferences to facilitate experience sharing from other countries is also necessary. Of course, the presence of the specialists alone cannot guarantee the success of revitalization because what is being taught matters. This brings us to the fourth goal: the curricula. The Indigenous language learning curricula has to be diversified. Three sets of curricula had been developed in the first Six-Year Project ("Words," "Daily Conversation," and "Reading and Writing"). Advanced-level curricula (such as "Cultural and Creative Work") and other diverse curricula will be developed, such as children's books, translated books, Indigenous literature, and grammar books. An online database on Indigenous language resources and e-learning website will be established under this project. Diversifying the Indigenous language curricula is the first step to fully recognize the language rights of the Indigenous peoples, which brings us to the fifth goal: language rights.

The meaning of language rights may be context-dependent. Language is a right to freedom, which shall be freely used by the people without interference by the State. At the same time, it is a social right that a State shall be obligated to promote. For Indigenous peoples, it is also a form of collective right, linked with the sustainability of its nation. Therefore, the key factor of whether this project can be successful depends on whether the state is honoring its constitutional obligation.

Lastly, the project also takes note in eliminating discrimination based on sex and promotes gender equality. The concept of gender identity and gender sensitivity shall be incorporated when implementing the Indigenous language revitalization at all stages.

\section{Indigenous Language Proficiency Certificate}

The Indigenous Language Proficiency Certificate was proposed in 2001. The Certificate provides four levels of proficiency ranking, including basic, intermediate, 
advance, and professional. No restriction was set on applicants' nationality, age, ethnicity, or education level. In 2014, the Indigenous language proficiency test required for the Affirmative Action for Indigenous Students was incorporated into the Indigenous Language Proficiency Certificate program. Currently, certifications are available for 16 language groups and 42 dialects and are given in 16 test sites. According to a survey conducted by the Council of Indigenous Peoples (2014a), most of the Certificates were granted for Amis, Paiwan, and Bunun languages. Between 2001 and 2011, a total of 17,165 people had applied for the certificate and 8321 people passed the test. The development of a test bank and practices tests was initiated in 2008 .

\section{Training of Indigenous Language Teachers}

No formal educational training is required for Indigenous language teachers at this point. The Council of Indigenous Peoples hosted training workshops to prepare fluent speakers who had obtained the Indigenous Language Proficiency Certificate to become teachers. By 2011, more than 4000 people had attended the workshops (Council of Indigenous Peoples 2014). Opportunity for observational learning was provided based on different curricula. A database of qualified Indigenous language specialists was built in 2008. More than 5000 people who had obtained the Indigenous Language Proficiency Certificate or had attended the training workshop were registered in the database (Council of Indigenous Peoples 2014).

\section{Online Learning Materials}

The Council of Indigenous Peoples developed online learning materials to meet the growing demand of online learning in the forms of online dictionaries, e-Books, and an e-learning platform.

Indigenous Language Online Dictionary (2016e) began its development in 2007. Sixteen online dictionaries are currently available, one for each of the 16 officially recognized tribes. The dictionary provides search functions from and to Mandarin Chinese. The dictionaries can be downloaded for offline use. Other learning materials on the website include downloadable vocabulary flashcards, vocabulary games and assessments. The website has on average 15,000 viewers per day, and a total of 9.8 million views up to June 2016 (Indigenous Language Online Dictionary 2016e).

Indigenous Language E-Park is the central platform for Indigenous languages learning, it provides downloadable textbooks, multimedia materials (videos and interactive children's books), online games, teaching materials and resources for teachers, and links relevantto Indigenous languages (Council of Indigenous Peoples 2016a). Another online e-learning platform is the Indigenous e-Learning website, which provides downloadable textbooks and teaching materials, video courses, and online courses (Indigenous e-Learning 2014b). Courses in vocabulary, songs, and stories are available for 14 Indigenous languages. There are currently a total of 
42 courses available on the website now. An Android App "Indigenous Language Genius" is also available (Council of Indigenous Peoples 2016a). It provides the learning curricula for grade 9-12. However, no statistics are yet available on the utilization frequency of these e-learning materials.

Taiwan Indigenous eBooks, which is available in both website and mobile App format, provides 355 eBooks in 16 different Indigenous languages. More than 7,000 reads had been recorded at the end of June 2016 (Taiwan Indigenous eBooks 2016c).

\section{Indigenous Language Research and Development Center}

Funded in 2013, the Indigenous Language Research and Development Center was established on the basis of Article 9 of the Indigenous Peoples Basic Law, which states "the government shall establish (a) special unit responsible for indigenous language researches and (an) indigenous language proficiency evaluation system in order to actively engage in the promotion of indigenous language development." The five mandated goals for the center included: (1) research on loanwords and new words; (2) research on the Indigenous Language Proficiency Certification test and the construction of a test bank; (3) research on Indigenous language teaching methods, including curricula assessment and development; (4) research on grammar and word formulation; and (5) research on Indigenous language revitalization (Indigenous Language Research and Development Center 2016f).

Some examples of the work accomplished by the center include hosting international conferences on Indigenous languages, translation of western literature texts into 16 Indigenous languages (Palemeq 2016) and publishing research findings on loanwords, new words, and the language revitalization process (Indigenous Language Research and Development Center 2016f). The center is also very active in disseminating information on social media to engage with a broader audience.

\section{Ministry of Education}

Prior to the establishment of the Council of Indigenous Peoples, the Ministry of Education had started to develop and compile Indigenous language curricula as part of its Indigenous Education Development and Improvement Projects. In 2006, the Ministry initiated the Indigenous Education Development Five-Year Midterm Case Project (2006-2010) to encompass Indigenous language teaching into the Local Dialect classes required for primary schools. The Ministry also developed learning assessment methods and a training system for Indigenous teachers. In higher education institutions, the Ministry of Education set up programs for Indigenous studies, task forces for Indigenous language teaching, and Indigenous Research and Development Centers.

To establish an Indigenous writing system, the Ministry first commissioned Professor Paul Jen-Kuei Li to develop the Austronesian Language Symbol System (1994). The system was later replaced by the Indigenous Language Writing 
System to ensure consistency (Council of Indigenous Peoples and Ministry of Education 2005).

Progress concerning indigenous education can be observed from the White Paper for Indigenous Education Policy (2011) published by the Ministry of Education. In the white paper, Indigenous languages education was pointed out as one of the key issues in Indigenous education (Ministry of Education 2011). Instead of having a ministry-wide program, small projects were implemented to promote Indigenous language education across different sectors in the Ministry. The Ministry of Education's annual educational report provides detailed examples of the programs that had been implemented in promoting Indigenous languages. To sum up, two measures can be delineated when it comes to promote indigenous languages: institutional reform and the development of language tools.

First, institutional reform took place within the educational system at both elementary and tertiary level. Indigenous language teaching was implemented at kindergarten level during 2014-2015, and grants were provided for local government to institute educational programs for this type of mother tongue language education. On the other hand, nine universities formed associations to train elementary school teachers and set up local language educational centers in schools. These centers are responsible for the development and promotion of local language programs.

Second, language tools were developed to facilitate an indigenous languagefriendly environment. The tools include "Taiwan Indigenous Language and History Encyclopedia," "Indigenous Language Wikipedia," Fifth Edition of the Basic Indigenous Language Teaching Materials, "Neologism for Indigenous Language," and "Indigenous Language Writing System." Awards and seminars were created to consolidate people's motivation to use these tools. These tools are further strengthened through programs and activities, including National Indigenous Reading and Speech Contest, Mother Tongue Language Contribution Award, and stipend provided to local organizations promoting Indigenous languages based on the Local Language Education Aid Policy.

\section{Local Governments}

Local governments refer to the 13 county governments and 6 municipal city governments in Taiwan. Every year the Council of Indigenous Peoples allocated budgets to collaborate with local governments and civil society organizations to establish "language nests" or "tribal classrooms," Indigenous language classes, and Indigenous cultural experience camps (Chao 2014). Successful implementation required strong will and collaboration effort from the local governments. Some local government also initiated efforts on Indigenous language educations in addition to the aids from the central governments. For example, Taipei City Government began the "Indigenous language nest" program in 2001, which provided $2 \mathrm{~h}$ of class each week for 11 Indigenous languages. In 2010, a total of 35 language nests teaching 10 languages had been established. On average, 378 people attended the 
language nests each month, but only $10.64 \%$ of them were under 18 years of age (Hsieh 2010). Other programs initiated by the Taipei City Government included holding training camps for Indigenous language teachers, editing Indigenous language textbook, hosting Indigenous cultural events, and broadcasting Indigenous language and culture education on the radio (Indigenous Peoples Commission of Taipei City Government 2003). Similar language nest programs were implemented by New Taipei City, Taoyuan City, Kaohsiung City, Hsinchu City, Tainan City, Taidong, Pingtung, Hualien, and Yilian. Other examples for promoting Indigenous language included hosting drama contests, vocabulary contests, and speech contests in Indigenous languages to raise learning incentives.

In 2016, the Pingtung County Government held an International Austronesian Language Education Forum for the first time. More than 250 Indigenous language education practitioners participated in the Forum. The Forum invited three international experts in Maori (New Zealand), Ainu (Japan), and Sami (Norway) languages to share their experiences on the language revitalization. The Forum not only generated tangible recommendations but also prompted local people to action. The impact of this local event was nationwide. The Forum engaged local Indigenous elders with scholars. This type of bottom-up effort showed that the awareness for Indigenous language revitalization is growing in Taiwan.

\section{Future Project}

In 2016, the Council of Indigenous People and the Ministry of Education joined efforts to develop an Indigenous Education Five-Year Midterm Development Project (2016-2020). The Project places an emphasis on "self-determination, equality, respect, diversity, and honor," with a center focus on "cultivating the next Indigenous generation and equipping them with competitiveness, cultural awareness, and self-determination" and to "regain basic rights, affirm fundamental learning, initiate cultural education, and practice multicultural goals." Language revitalization and promotion were not stated directly in the project (Council of Indigenous Peoples and Ministry of Education 2015). To achieve a true practice of cultural education, a solid plan of Indigenous language revitalization must be established. The Project, which laid out 12 strategies, 35 execution items, and 148 specific actions, lacked of tangible focus on Indigenous languages. A detailed plan for language reconstruction for Indigenous education is highly recommended by the authors of this chapter. Other observation based on the direction and actions of the 2016-2020 Five-Year Project included:

1. The trend to self-learning has begun even with limited policy endorsement and funding. With time and more policy endorsements, it will become a common norm.

2. Through years of discussion, concrete policies and legal bases have been established for Indigenous education. More funding is also available. Indigenous peoples' opinions have been more accepted by mainstream society. 
3. Though the overall condition of Indigenous peoples is improving, there are still traces of discrimination toward this minority population. It is a long road with many challenges waiting for Indigenous education toward sustainability and maturation.

4. Many of the languages for the smaller tribes are nearly impossible to revitalize. However, digital recording can help keep records of these languages, in hopes that these endangered languages could be preserved for future revitalization efforts.

\section{Challenges on Indigenous Language Education}

Despite efforts, Indigenous language development in Taiwan continues to face challenges. In identifying these challenges, it enables us to see where we can further progress. First, one of the biggest challenges has been a lack of coherent policy direction taken by the Ministry of Education and the Council of Indigenous Peoples. These two government agencies have carried out parallel and duplicate efforts on Indigenous language education. The inadequate collaboration results in wasted resources and time. For instance, the Ministry of Education previously spent millions of Taiwanese dollars on developing local dialect curricula for 13 different Indigenous languages, but they were later shelved (Chao 2014). The lack of consensus on the Indigenous Writing Systems in the beginning also staggered the revitalization progress. Horizontal communications between central governmental agencies and vertical communications between central governmental agencies, schools, and local governments were laborious, and very little attention was paid to assessing project outcomes (Hung 2014). This problem has been noted and addressed in the most current Indigenous Education Five-Year Midterm Development Project, which is a joint project by the Ministry of Education and the Council of Indigenous Peoples. Effective communication between the Ministry of Education and the Council of Indigenous Peoples is central to creating sustainable collaboration.

Second, not having an independent system to train Indigenous language teachers is a severe challenge to sustain indigenous language education. The initial approach by the Ministry of Education was to train Indigenous schoolteachers who already held valid teaching licenses to become Indigenous language teachers. Short-term training workshops on Indigenous languages were available to the teachers. However, most of the Indigenous schoolteachers did not have the ability to speak Indigenous languages fluently; thus, most of the teaching was accomplished by Indigenous language specialists who did not have any formal education training (The Education and Culture Committee of the Control Yuan 2003). Indigenous schoolteachers were not required to attend the language workshops to teach Indigenous languages, and there exists no assessment of their language proficiency. For Indigenous language specialists who do not hold a teaching license, they must obtain Indigenous Language Proficiency Certification in order to teach in public schools. The Indigenous language specialists responsible for the actual teaching expressed that Indigenous language education does not have a clear place in the school system 
and most schools lack Indigenous cultural sensitivity (Huang 2004). The Ministry of Education has made some progress to incorporate Indigenous language in higher education institutions, such as the institution of local language educational centers in universities (Ministry of Education 2015). A formal education program for Indigenous languages teachers can help them gain more respect in the schools and facilitate the promotion of Indigenous languages in the formal education system. Because there is no independent training system, Indigenous language teachers gain their qualifications by cobbling together fragmented policies. Consequently, teaching indigenous languages is still largely ignored by the formal education system. For this reason, it is necessary that Indigenous peoples need to have our own independent training system.

Third, Indigenous peoples' language revitalization cannot be realized without an increase in designated teaching hours coupled with additional resources. Currently, only one class $(40 \mathrm{~min})$ is allocated for Indigenous language per week in public schools (first grade to ninth grade). The effect of a single hour of language learning per week is minimal. Most schools schedule the class during nonofficial class hours (early mornings or weekends). Some schools mix students from different grades or different languages in the same class. The lack of classroom space forces some teachers to teach in the gym or in the hallway. Indigenous language specialists who assist in teaching primary schools usually did not have enough support or respect from school officials. Many of them need to travel from school to school in order to maintain full-time employment status (Hung 2014). These conditions discourage passionate teachers and create new obstacles to guaranteeing Indigenous peoples' rights to a sustainable language education.

Fourth, a proper legislative framework is urgently needed to promote indigenous languages at the preschool level. The critical window for learning language is between 5 and 7 years old. Indigenous language immersion preschool can lay the foundation for Indigenous language learning (Pawan 2006). There are currently 20 experimental Indigenous language-immersion kindergartens (Council of Indigenous Peoples 2016b). The lack of legislative framework leads to insufficient funds and resources for the preschool level.

Following are tentative recommendations to meet the challenges delineated above. The following aspects are important for the future work of promoting indigenous language education. Firstly, identify those who are still able to speak indigenous languages fluently. These people are key to revitalize indigenous languages and preserve indigenous language-friendly environments. More awareness for language rights in schools and other public sectors needs to be generated. In addition, the revitalization process will benefit from the self-initiating wills from each tribe. Each tribe should be given the resources and power to manage and revitalize its own language and create a safe and convenient environment to practice these languages. Furthermore, family is the foundation to establish good learning environment for Indigenous languages. Increasing the number of children who start learning Indigenous languages from an early age is the most sustainable way to save endangered languages. Secondly, an adequate allocation of resources from the central government to local governments and institutions is necessary. Empowering 
those people who work closely with their own culture and language will help maximize the effects of revitalization. Retired Indigenous persons would prove an enormous asset to help educate the new generation to speak Indigenous languages. Third, creation of a platform for experience exchanges can allow experts and scholars to work collectively toward language preservation and revitalization that attracts new talent. For example, international conferences on Indigenous language education are an effective means to highlight the importance of practicing Indigenous languages in daily life. The platform can also document the efforts for longterm assessment and evaluation.

Finally but importantly, the journey of language revitalization should be conceptualized in a long-term scale where new ideas and innovations are constantly being incorporated. Many Indigenous languages are slowly being replaced by mainstream languages; new ideas are currently needed for language revitalization, especially for those languages that are on the brink of extinction. Revitalization is possible with the help of the government, academia, and NGOs. Endangered languages require more attention and specially dedicated research teams to persist long term in helping local tribes maintain their linguistic identities by creating a lively learning environment.

\section{Conclusion}

Recent international trends and new policies brought new opportunities and acceptances for Indigenous languages in Taiwan. Indigenous languages are vital to Indigenous peoples' identities and community development, but the extent of achieving revitalization is linked to Indigenous peoples' social status. Many Indigenous peoples have not yet realized the importance of language revitalization because they are under great social and economic pressure. In addition, the lack of Indigenous language specialists is the biggest concern for Indigenous language development in Taiwan. Indigenous people need to utilize these given revitalization resources and work toward a common goal. This chapter aims to serve as a reference for the international Indigenous language education community and also act as a starting point for future language revitalization for Indigenous peoples in Taiwan.

\section{References}

Bellwood P (1991) The Austronesian dispersal and the origin of languages. Sci Am 265:88-93. https://doi.org/10.1038/scientificamerican0791-88

Blust R (1984) The Austronesian homeland: a linguistic perspective. Asian Perspect 26(1):45-67

Chao $\mathrm{S}-\mathrm{C}$ (2014) Táiwān yuán zhù mínzú yǔ jiàoyù zhèngcè zhī pīpàn lùnshù fēnxī (The critical discourse analysis of Taiwan Indigenous language education policy). Kèchéngyánjiū (J Curric Stud) 9(2):053-078. https://doi.org/10.3966/181653382014090902003

Chen L-Y (2004) Táiwān yuán zhùmín yùndòng yǔ yuán zhùmín jiàoyù zhèngcè guānxì zhī tàntăo (The relationship between policy and Indigenous movements for Indigenous education in Taiwan). Yuán zhùmín jiàoyù jikān 34:27-46 
Council of Indigenous Peoples (2014a) Yuán zhù mínzú jiàoyù diàochá tǒngjì (Indigenous education survey). http://www.ns.org.tw/download.asp. Accessed 22 June 2017

Council of Indigenous Peoples (2014b) Indigenous e-Learning. http://e-learning.apc.gov.tw/ default.aspx. Accessed 24 June 2016

Council of Indigenous Peoples (2016a) Indigenous language network. http://web.klokah.tw. Accessed 24 June 2016

Council of Indigenous Peoples (2016b) Jìntòu shì zú yǔ jiàoxué yòu'éryuán (Immersion Indigenous language Kindergarten). http://kindergarten.klokah.tw. Accessed 22 June 2017

Council of Indigenous Peoples (2016c) Taiwan Indigenous eBooks. http://alilin.apc.gov.tw/tw. Accessed 24 June 2016

Council of Indigenous Peoples (2016d) Yuán zhù mínzú yǔyán diàochá yánjiū sān nián shíshī jì huà (3 year project on Indigenous language survey). http://alilin.apc.gov.tw/files/ebook/ 30617674756c2e9fc961d7/_SWF_Window.html. Accessed 22 June 2017

Council of Indigenous Peoples (2016e) Indigenous language online dictionary. http://e-dictionary. apc.gov.tw/Index.htm. Accessed 24 June 2016

Council of Indigenous Peoples (2016f) Indigenous Language Research and Development Center. http://ilrdc.tw/. Accessed 24 June 2016

Council of Indigenous Peoples and Ministry of Education (2005) Yuán zhù mínzú yǔyán shūxiě xìtǒng (Indigenous language writing system). http://dore.tacp.gov.tw/tacp/ebook/apc110003 bbog_oth20090813031/index.html. Accessed 22 June 2017

Council of Indigenous Peoples and Ministry of Education (2015). Fāzhăn yuán zhù mínzú jiàoyù wǔ nián zhōng chéng jì huà 105-109 (Five-year Indigenous education development midterm project, 2016-2020). Taipei

Digital Museum of Taiwan Indigenous Peoples (2016) Yuán zhùmín wénhuà nián biăo (Indigenous culture chronology). http://www.dmtip.gov.tw/Museum/Article.aspx?CategoryID $=15$. Accessed 22 June 2017

Education Act for Indigenous Peoples (1998). Ministry of Education, Republic of China (Taiwan)

Hsieh J-L (2010) Xuéxí shèqū huà huóluò dūshì yuán zhù mínzú yǔ (Community learning of Indigenous languages in urban areas) Táiběi yuányě diànzǐ bào, 20. http://epaper.taipei.gov.tw/ public/epaperHTML/08251232871/04.htm?id=n04. Accessed 22 June 2017

Huang LM-J (2004) Táiwān yuán zhù mínzú yǔ jiàoyù xiànkuàng jí zhănwàng - zú yǔ zǒngtĩ xuéxí huánjìng zhī yíngzào (Current situation and prospect of Indigenous language education in Taiwan - create comprehensive learning environment of the Indigenous language). In: Ethnic and cultural development conference, Taipei

Huang LM-J (2015) Development and future prospective on Indigenous languages Indigenous. Language Research and Development Center 2015 annual report round table discussion, 15 Dec 2015, Taipei

Hung Y-Y "Sukudi” (2014) Yuán zhù mínzú zú yǔ jiàoxué zhī wǒ jiàn (My view on Indigenous language education). Xīn shìjì zhìkù lùntán 65:48-51

Indigenous Peoples Commission of Taipei City Government (2003) A special report of Indigenous language nest in Taipei. Indigenous Peoples Commission of Taipei City Government, Taipei

Lee H-H (2004) Táiwān lìshǐ gè shíqí yǔyán zhèngcè zhī fēnxī bǔjiào (Comparison of language policy in each historic period in Taiwan). In: Yǔyán rénquán yǔ yǔyán fù zhèn xuéshù yántăo huì lùnwén jí. Department of Language Education at Taidong Univeristy, Taidong

Li PJ-K (1994) Zhōngguó yǔwén táiwān nándăo yǔyán de yǔyīn fúhào xìtǒng (Chinese language Taiwan Austronesian language symbol system). Ministry of Education, Republic of China (Taiwan), Taipei

Li T-Y (2007) Táiwān yuán zhù mínzú yǔyán yánjiū shǐ jí qí pínggū (The history of the research on Taiwanese Aboriginal languages and the evaluation of the research history). Zhèngdà mínzú xuébào 26:165-190

Lim S-T (2003) Yuán zhù mínzú de zú yǔ jiàoyù gàikuàng (Overview of Indigenous language education). Yánxí zīxùn 20(1):35-40 
Ministry of Education (2011) White book on Indigenous education. Ministry of Education, Republic of China (Taiwan), Taipei

Ministry of Education (2015) 104 Yuán zhùmín jiàoyù tuīdòng chéngxiào gàikuàng bàogào (Annual progress report on the promotion of Indigenous education in Taiwan). https://indige nous.moe.gov.tw/EducationAborigines/Article/Details/3059. Accessed 24 June 2016

Palemeq Y (2016) Connect with the world through translation: a case with Taiwanese Indigenous languages. The development of Taiwanese Indigenous media and languages on 31th May, 2016 at Festival of Pacific Arts, Guam

Palemeq Y, Muzuer A (2015) Relevant regulations on Indigenous languages in Taiwan. Indigenous Language Research and Development Center. http://ilrdc.tw/research/policy/law.php. Accessed 24 June 2016

Pawan C (2006) Cóng niǔ xī lán máolì zú de yǔyán cháo kàn táiwān de yuán zhùmín mǔyǔ jiàoxué (From Maori language nest to reflect Indigenous language education in Taiwan). Taiwan Int Stud Q 2(1):163-184

RIS (2016) Tái mǐn xiàn shìyuán zhù mínzú rén $\square \square$ kǒu (Census on Indigenous population). Ministry of the Interior, R.O.C (Taiwan), Taipei

Sawtoy S (2016) Oral folklore and literature of love. The development of Taiwanese Indigenous media and languages on 31th May, 2016 at Festival of Pacific Arts, Guam

Taiwan Indigenous People's Knowledge Economic Development Association (2016) Distribution of Indigenous peoples in Taiwan. http://www.twedance.org/aboriginal00.aspx. Accessed 24 June 2016

The Education and Culture Committee of the Control Yuan (2003) An investigation study on the problems of native language instruction in the elementary school. The Control Yuan, Taipei

The First 6-Year Indigenous Cultural Revitalization and Development Project (1999) Council of Indigenous Peoples, Republic of China (Taiwan), Taipei

The First 6-Year Indigenous Language Revitalization Project (2008) Council of Indigenous Peoples, Republic of China (Taiwan), Taipei

The Second 6-Year Indigenous Cultural Revitalization and Development Project (2008) Council of Indigenous Peoples, Republic of China (Taiwan), Taipei

The Second 6-Year Indigenous Language Revitalization Project (2014) Council of Indigenous Peoples, Republic of China (Taiwan), Taipei

Zeitoun $\mathrm{E}$ Yu $\mathrm{CH}$, Weng $\mathrm{CX}(2003)$ The Formosan language archive: development of a multimedia

Linguist 42(1):218-232 